\title{
The Mechanism of lodine Enrichment in Groundwater from the North China Plain: Insight from Two Inland and Coastal Aquifer Sediment Boreholes
}

\section{Xiaobin Xue}

Yangtze River Basin Ecological Environment Monitoring and Scientific Research Center, Yangtze River Basin Ecological Environment Supervision and Administration Bureau, Ministry of Ecological Environment, China

Xianjun Xie ( $\nabla$ cug_xxj@163.com)

China University of Geosciences https://orcid.org/0000-0001-8695-1517

Junxia Li

CUG: China University of Geosciences

\section{Yuting Wang}

CUG: China University of Geosciences

\section{Yanxin Wang}

CUG: China University of Geosciences

\section{Research Article}

Keywords: iodine, pore water, adsorption/desorption, marine influence, groundwater

Posted Date: September 27th, 2021

DOI: https://doi.org/10.21203/rs.3.rs-698129/v1

License: (c) (i) This work is licensed under a Creative Commons Attribution 4.0 International License. Read Full License

Version of Record: A version of this preprint was published at Environmental Science and Pollution Research on February 25th, 2022. See the published version at https://doi.org/10.1007/s11356-02118078-x. 


\section{Abstract}

As an element relevant to human health, iodine is highly worthy of researchers' attention, especially the mechanism of iodine migration and enrichment in groundwater systems. A total of 43 groundwater, 1 seawater, 107 sediment and 111 pore water samples from two boreholes (toward to Bohai Sea: BT, HH) were collected along a groundwater flow path at the North China Plain to investigate hydro-geochemical processes controlling groundwater iodine. High iodine groundwater $(>100 \mu \mathrm{g} / \mathrm{L})$ was characterized by $\mathrm{Na}-\mathrm{Cl}$ type, with high TDS values (827-2,400 mg/L) and high $\mathrm{Cl}(110-705 \mathrm{mg} / \mathrm{L})$ and $\mathrm{Br}(416-1,180 \mu \mathrm{g} / \mathrm{L})$ concentrations, which may be related to marine influence. Borehole BT and $\mathrm{HH}$ had pore water I concentration ranges of $1.4-132 \mu \mathrm{g} / \mathrm{L}$ and $3.6-830 \mu \mathrm{g} / \mathrm{L}$, with high level occurred near to coastline and corresponded to ancient transgression events. The results of sequential extraction of borehole sediments indicate that the fractions of sediment inorganic iodine were mainly consist of exchangeable, carbonate and Fe-oxides associated fractions. Fe-oxides associated iodine was the main occurrence state in borehole BT far from the coastline, but high exchangeable iodine fractions (up to $92 \%$ of total extracted iodine) were observed in a high salinity borehole $\mathrm{HH}$ located near Bohai Bay, corresponding to the occurrence of high iodine pore water and groundwater. The analysis of iodine species indicates that iodide with strong migration ability dominated high iodine groundwater, pore water and exchangeable sediment iodine, reflecting the occurrence of adsorption/desorption processes of iodine in groundwater system. High iodine groundwater and pore water exhibited iodine enrichment relative to $\mathrm{Cl}$ and $\mathrm{Br}$, suggests that iodine adsorbed on sediment desorbed under suitable $\mathrm{pH}$ and high solution ionic strength and subsequently released to pore water and aquifers. Inverse geochemical modeling stressed that ion exchange play an important role in iodine enrichment of groundwater system.

\section{Introduction}

lodine is a constituent of the hormones triiodothyronine $\left(\mathrm{C}_{15} \mathrm{H}_{11} \mathrm{I}_{4} \mathrm{NO}_{4}\right)$ and thyroxine $\left(\mathrm{C}_{15} \mathrm{H}_{12} \mathrm{I}_{3} \mathrm{NO}_{4}\right)$, which mainly occur in the thyroid gland of mammals and play an important role in energy metabolism, thermoregulation, and physical and mental development of the human body. Endemic thyroid diseases are associated with excessive iodine intake from drinking water, and have become a serious and common public health problem around the world (e.g. Kassim et al. 2014; Voutchkova et al. 2014). In China, the national standard for the maximum concentration limit (MCL) of iodine in drinking water is $100 \mu \mathrm{g} / \mathrm{L}$ (GB/T 19380 - 2016), and high iodine groundwater (> $100 \mu \mathrm{g} / \mathrm{L})$ can be regarded as a vital factor threatening residents' health. Recent research verified 12 provinces had excessive iodine in drinking water and over 30 million people were exposed to the high iodine risk (Zhang et al. 2010; Wang et al. 2018). Beijing, Tianjin, Hebei, and Henan provinces are the most concerning, and all are located on the North China Plain (NCP). As one of the most populous regions in the world, the NCP has become a hotspot with respect to groundwater resource depletion and water quality degradation in the past few decades. Some studies conducted on high iodine groundwater of the NCP suggest reductive dissolution of iron oxides (based on species analysis and geochemical modeling), degradation of organic matter (based on hydrochemisty, biomarker and carbon isotopes), and sediment compaction (based on hydrochemisty and 
$\mathrm{H}, \mathrm{O}, \mathrm{Sr}$ isotopes) play roles in the enrichment of iodine in groundwater (Zhang et al. 2013; Li et al. 2017; Xue et al. 2019a, b). These studies have concerned about complex biogeochemical or physical process, but not conducted detailed analysis of the carrying form of active iodine loaded on sediments and the effects of water-sediment interaction process on the iodine enrichment. Furthermore, inland and coastal aquifer system has different geochemical characteristics, and it is of significance to reveal the influence of marine-affected sediment on iodine enrichment in groundwater system.

lodine in the environment mainly exists in the ocean, which represents a critical reservoir of iodine on Earth and the major source in its environmental cycle (Muramatsu and Wedepohl 1998; Fuge and Johnson 2015). It has long been established that iodine is enriched in marine organisms, which can show a general enrichment factor of over 30,000 relative to seawater (Fuge and Johnson 1986; Ar Gall et al. 2005; de la Cuesta and Manley 2009). Other studies have clearly shown that inshore soils contain high iodine concentrations (about $10-60 \mathrm{mg} / \mathrm{kg}$ ), while the iodine concentration in soils far from marine influences is relatively depleted (about $0.5-3 \mathrm{mg} / \mathrm{kg}$ ) (Johnson 2003; Fuge and Johnson 2015). This indicates soils subject to marine influence are likely to affect the concentration of iodine in groundwater after their burial and sedimentation. It is generally believed that the cycle of iodine is closely to the water cycle, especially for the ground surface and atmosphere. But the transport of subsurface iodine is neglected, and the behavior of iodine under the water-sediment interaction has not been revealed.

Recent research shows inorganic components can adsorb iodine and participate in the composition of major minerals; for example, Nagata and Fukushi (2010) suggest iodine can adsorb onto metal oxides, and Podder et al. (2017) show iodine can participate in the crystal structure of calcium carbonates. Sorption to sedimentary minerals surfaces was supposed to impact iodine mobilization from conceptual overview of underground biogeochemical processes conducted by Truex et al. (2017). Besides, Moore et al. (2020) have reviewed that inorganic materials immobilized iodine by sorption or by redox process coupled with sorption, such as apatite, sulfur-based, copper-based, bismuth-based materials, and etc. This indicates the inorganic component should play an indispensable role in the iodine migration of groundwater system. lodine can be found in various oxidation states ranging from -1 to +7 and a range of inorganic and organic forms including iodide $\left(\mathrm{I}^{-}\right)$, iodate $\left(\mathrm{IO}_{3}{ }^{-}\right)$, elemental iodine $\left(\mathrm{I}_{2}\right)$, and organic iodine. lodide and iodate are the most common species in natural aqueous systems and their adsorption ability has a significant impact on mobility. lodate can sorb significantly more than iodide (Nagata and Fukushi 2010), with the latter widely used as a tracer in previous studies (Razafindratsima et al. 2015). However, it has not been well-understood for the role of iodide and iodate with different geochemical behavior in iodine-rich groundwater.

The objectives of this study were to (1) depict hydrochemistry evolution characteristics of groundwater and pore water from sediments along the typical flowpath of the NCP, (2) investigate the loading of iodine on marine-affected sediments, and (3) reveal the control of adsorption/desorption process on iodine enrichment in the groundwater system. This was accomplished using sequential extraction, an effective method to study the occurrence, state, and migration of elements that can be used to determine the exchangeable iodine, iodine binding to carbonate, and iodine binding to Fe-oxides (Tessier et al. 1979). 
Combined analysis of sediment samples, pore water from two long boreholes and groundwater along the flow path were considered to evaluate iodine loaded onto sediments within Quaternary aquifers and potential controlling processes on iodine mobilization in the groundwater system of the NCP.

\section{Study Area}

The NCP is located in the eastern part of China with a total area of $\sim 140,000 \mathrm{~km}^{2}$ and an altitude of $\leq$ $100 \mathrm{~m}$ asl. The NCP is covered by Cenozoic sediments that range from 50 to $2500 \mathrm{~m}$ thick and its bedrock is mainly comprised of a suite of complicated strata of Pre-Cambrian metamorphic rocks, Cambrian and Ordovician limestones, and Carboniferous and Permian sandstone shales. The Quaternary strata are 20 to $600 \mathrm{~m}$ thick with a lithology of mainly clay, clayey silt, silt, and sand. Dispersed pebble beds occur in the piedmont area and laminated fine silt or clay mainly occurs in the coastal area. These sediments are dominated by alluvial deposits with interbedded marine deposits in the littoral plain. The three main rivers-the Yellow River, Hai River, and Luan River-along with their tributaries, play a role as discharge channels for the groundwater system and variably act as sources of recharge to the unconfined aquifer. Due to sea level fluctuations during the Quaternary, marine transgression and regression events took place on the coastal plain sequentially from the Early Pleistocene to the Holocene, including the Bohai, Haixing, Huanghua, Baiyangdian, Cangzhou, and Tianjin transgressions (Lin and Dai 2012). Representing a typical section in the middle of the NCP, the study area runs from the piedmont regions of the Taihang Mountain in the west and drains into the Bohai Sea in the east (Fig. 1).

According to sedimentary characteristics and relative geographic positions, the NCP is traditionally separated into three primary hydrogeological zones from west to east: the piedmont region, central plain, and coastal plain (Wu et al. 1996). The three zones have special hydrogeological roles in the groundwater flow system as the main recharge (I), runoff (II), and discharge zones (III), respectively. Recharge for shallow unconfined groundwater mainly occurs in the piedmont region because of the coarse soil texture, and natural discharge occurs through evapotranspiration in the coastal plain. Precipitation, irrigation return flow, infiltration of surface water flow in rivers and canals, and lateral inflow are potential sources of shallow groundwater recharge (Zhang et al. 1997). Under pumping conditions, deep groundwater may receive groundwater leakage from the shallow aquifers due to the enhanced downward hydraulic gradient, compaction-released pore water, and inter-aquifer in the coastal area (Cao et al. 2013). Extensive exploitation of groundwater for irrigation and drinking water has caused a more rapid decline in groundwater levels, and resulted in regional land subsidence accompanied by compaction of compressible clay and a large amount of pore water entering aquifers (Guo et al. 2015).

The Quaternary aquifers, composed of sandy gravel and medium fine-grained sand with interlayers of silt and clay, contain sediment under the influence of marine transgression in the coastal area. Four major aquifer units are generally defined from top to bottom as Aquifers I, II, III, and IV, respectively (Zhang 2005). Aquifer I (formed in the Holocene) is an unconfined aquifer at a depth of 10 to $50 \mathrm{~m}$, consisting of medium sand in the piedmont and fine-grained sand in the littoral plain. The depth to the groundwater table is $\sim 2-3 \mathrm{~m}$, and the specific yield is about $1-2.5 \mathrm{~m}^{3} / \mathrm{hm}$. Groundwater is $\mathrm{Ca}-\mathrm{HCO}_{3}$ type with TDS < 
$0.7 \mathrm{~g} / \mathrm{L}$ in the piedmont and $\mathrm{Na}-\mathrm{Cl}$ type with TDS $>2 \mathrm{~g} / \mathrm{L}$ in the central and littoral plain (maximum value $9 \mathrm{~g} / \mathrm{L}$ ). Aquifer II (formed in the late Pleistocene) is located at a depth of $\sim 150 \mathrm{~m}$ and consists of fine sand and silt. The groundwater hydrochemistry is similar to Aquifer I. Aquifers III and IV (formed in the middle and early Pleistocene) are hydraulically connected and are currently the main exploitation layers for water resources. Aquifer III, at a depth of 250 to $350 \mathrm{~m}$ and with a thickness of about 25 to $60 \mathrm{~m}$, is a confined aquifer consisting of fine sand. The specific yield is about $5-10 \mathrm{~m}^{3} / \mathrm{hm}$. The groundwater is $\mathrm{Na}-\mathrm{Cl}-\mathrm{HCO}_{3}$ type with TDS values $1-3 \mathrm{~g} / \mathrm{L}$. Aquifer IV, at a depth of about $\sim 550 \mathrm{~m}$, has a thickness of 20 to $50 \mathrm{~m}$ and consists of fine sand and silt. The specific yield is less than $2.5 \mathrm{~m}^{3} / \mathrm{hm}$. The groundwater is $\mathrm{Na}-\mathrm{Cl}-\mathrm{HCO}_{3}$ type with TDS values $1-3 \mathrm{~g} / \mathrm{L}$ (Zhang et al. 2000; Chen et al. 2003; Kreuzer et al. 2009).

\section{Methods}

\subsection{Sampling profiles}

For this study, one groundwater flow path was selected that extended from Shijiazhuang, through Hengshui and Botou, to Huanghua, with a total length of about $380 \mathrm{~km}$. It was located in the north of the NCP, starting from Taihang Mountain and ending in Bohai Bay. 43 groundwater samples were collected from wells with depths between 50 and $600 \mathrm{~m}$ corresponding mainly to Aquifer III and IV along the groundwater flow path, which is the supply of local drinking water (Fig. 1). Shallow wells (depths $<100$ $\mathrm{m}$ ) were mainly in front of the mountain where the thickness of the Quaternary strata was less than 100 $\mathrm{m}$. Groundwater was sampled from each well after pumping (usually $10 \mathrm{~min}$ ). Groundwater field parameters, including $\mathrm{pH}$ and redox potential (ORP), were measured in situ using a portable multiparameter meter (HACH, HQ40D). One seawater sample was collected from Bohai Bay at the end of groundwater flow path. Chemical and physical parameters, including $\mathrm{pH}$ and ORP, were measured on site using Hach portable meters after stabilization. All water samples were collected in HDPE containers using vacuum filtration and filtered through $0.45-\mu \mathrm{m}$ membranes. Samples for cation analysis were acidified using ultra-purified $\mathrm{HNO}_{3}$ to $\mathrm{pH}<2$, and samples for anion analysis were collected directly after being filtered. Samples for iodine species analysis were filtered through $0.45-\mu \mathrm{m}$ membranes when sampling and collected in iodine-free brown plastic bottles without headspace.

Sediment boreholes BT (depth: $322 \mathrm{~m}$ ) and HH (depth: $386 \mathrm{~m}$ ) are distributed along the groundwater flow path (Fig. 1). Borehole BT is located in the runoff area, and boreholes $\mathrm{HH}$ are located in the coastal area, with $\mathrm{HH}$ closer to Bohai Bay. Borehole sediments were collected in the area where groundwater had a total iodine concentration transitioning from low $(<100 \mu \mathrm{g} / \mathrm{L}$ ) to high (from 100 to $1110 \mu \mathrm{g} / \mathrm{L}$ ). A total of 107 sediment samples were collected from three boreholes using vacuum packing after remove external turbulent and stored at $4{ }^{\circ} \mathrm{C}$ to minimize the change in chemical composition.

\subsection{Groundwater chemistry analysis}

Alkalinity was determined using the hydrochloric acid titration method within $24 \mathrm{~h}$ of sampling. Concentrations of major anions in unacidified aliquots were determined by ion chromatography (IC) 
(Metrohm 761 Compact). The analytical precision of anion analysis was $<5 \%$. Cations were determined using inductively-coupled plasma optical emission spectroscopy (ICP-OES; iCAP 6300, Thermo) with an analytical precision of $5 \%$. Charge balance errors for all groundwater samples were $<8 \%$. Trace element analysis, including bromide and iodine concentration, was conducted using inductively-coupled plasma mass spectrometry (ICP-MS; Agilent 7900). lodine species (iodate and iodide) were separated and measured by high performance liquid chromatography-ICP-mass spectrometry (HPLC-ICP-MS; Agilent 1260; Agilent 7900; AG 20 analytical column, ICS-1500, Dionex). The organic iodine concentration was calculated by deducting the concentration of iodate and iodide from the total iodine concentration. All samples subjected to iodine and bromide analysis had a precision better than $5 \%$.

\subsection{Sediment geochemistry analysis}

One sample every $5 \mathrm{~m}$ from the borehole sediment was used to grain size analysis and performed by a laser particle size analyzer (Mastersizer 3000, Malven Instrument Ltd. UK). All samples were then crushed and ground to less than 200 mesh size in the laboratory. A portable multi-parameter meter $(\mathrm{HACH}$, HQ40D) was used to measure the electrical conductivity (EC) of sediment suspension with sediment to water ratio of 1:5. Sediment total organic carbon (TOC) was analyzed by an element analyzer (Vario TOC, Elementar) after the removal of inorganic carbon by hydrochloric acid. Major elements of sediments were determined by ICP-OES (IRIS Intrepid II XSP) after digestion of $\mathrm{HNO}_{3}+\mathrm{HF}+\mathrm{HClO}_{4}$.

As proposed by Tessier et al. (1979) and modificated by Hou et al. (2003), a sequential extraction was conducted to determine extractable iodine in sediments. lodine in the organic fraction is discounted due to the low total organic matter content in the sediments. To understand iodine mobilization in the groundwater system, three fractions of extracted iodine were selected: 1) the exchangeable fraction, extracted with $0.005 \mathrm{M} \mathrm{KCl}$ and then $0.1 \mathrm{M} \mathrm{KCl}$; 2) carbonate associated, extracted with $0.44 \mathrm{M}$ acetic acid in $0.1 \mathrm{M} \mathrm{KCl}$; and 3) Fe-oxides associated, extracted first with $0.01 \mathrm{M} \mathrm{NH}_{2} \mathrm{HCl}$ in $0.1 \mathrm{M} \mathrm{HNO}_{3}$ at room temperature and then with $0.04 \mathrm{M} \mathrm{NH}_{2} \mathrm{HCl}$ in $0.1 \mathrm{M} \mathrm{HNO}_{3}$ at $96^{\circ} \mathrm{C}$. After each extraction step, the slurry was centrifuged at low speed (4000 rpm) to separate the aqueous phase with the extracted iodine from the sediment, then the supernatant was filtered through a $0.45-\mu \mathrm{m}$ membrane to ensure the removal of fine particles. lodine in the form of iodate and iodide in each extracted fraction was measured by HPLCICP-MS. The total extracted iodine concentration reported is calculated by the total of the three fractions (exchangeable, carbonate associated, and Fe-oxides associated). All samples subjected to iodate and iodide analysis had a precision better than $5 \%$, with a reproducibility of $<6 \%$.

\subsection{Pore water extracted from sediments}

In order to better understand the chemical characteristics of pore water in aquitards (silty clay), a squeezing method of extracting pore water was adopted and a schematic diagram of the mechanical press apparatus was shown in Fig. A1. Detailed operating procedures have been addressed in our previous study (Xue et al. 2019a). A total of 21 sediment samples were conducted on compaction experiment and 111 pore water samples were obtained during the increase of pressure. Because of the limited amount of samples, these pore water samples were only tested for anions, including $\mathrm{Cl}, \mathrm{Br}$. And 
lodine and their species were performed the same as those in groundwater with a precision better than $5 \%$ and a reproducibility of $<6 \%$.

\section{Results}

\subsection{Evolution of groundwater chemistry}

Geochemical characteristics of groundwater samples from along the studied flow path in the NCP are summarized in Table A1 and presented as three regions (I: recharge area; II: runoff area; III: discharge area) according to the difference of hydrogeological conditions. In the region I and II, groundwater samples exhibit a slightly wider $\mathrm{pH}$ range between 7.25 and 8.55 and a relatively positive ORP value varying from 86 to $170 \mathrm{mV}$, indicating a weak reduction or oxidation condition (Fig. 2a and 2b). TDS values range from 269 to $866 \mathrm{mg} / \mathrm{L}$ with a median of $661 \mathrm{mg} / \mathrm{L}$ and are relatively low, indicating fresh water of recharge and runoff area. Groundwater samples have a $\mathrm{Na}^{+}$concentration range of 14 to 350 $\mathrm{mg} / \mathrm{L}$ with a median of $98 \mathrm{mg} / \mathrm{L}$, a Ca ${ }^{2+}$ concentration range of 7.7 to $189 \mathrm{mg} / \mathrm{L}$ with a median of 39 $\mathrm{mg} / \mathrm{L}$ and a $\mathrm{Mg}^{2+}$ concentration range of 3.1 to $31 \mathrm{mg} / \mathrm{L}$ with a median of $14 \mathrm{mg} / \mathrm{L}$. Alkalinity expressed as $\mathrm{HCO}_{3}{ }^{-}$ranges from 92 to $478 \mathrm{mg} / \mathrm{L}$ with a median of $289 \mathrm{mg} / \mathrm{L}, \mathrm{SO}_{4}{ }^{2-}$ ranges from 23 to $274 \mathrm{mg} / \mathrm{L}$ with a median of $143 \mathrm{mg} / \mathrm{L}$, and $\mathrm{Cl}^{-}$concentrations range from 7.2 to $263 \mathrm{mg} / \mathrm{L}$ with a median of 64 $\mathrm{mg} / \mathrm{L}$. These indicate groundwater from region I and II is mainly characterized by $\mathrm{Ca}-\mathrm{HCO}_{3}$ and $\mathrm{Na}-\mathrm{HCO}_{3}$ type, respectively (Table A1; Fig. 3).

In the region III, groundwater has a narrow pH range of 7.8 to 8.34 and a ORP range of -214 to $126 \mathrm{mV}$, indicating weak alkaline and from reducing to oxidizing condition. Compared to region I and II, TDS values of groundwater samples from region III had a high level of $892-2400 \mathrm{mg} / \mathrm{L}$ with a median of 1500 $\mathrm{mg} / \mathrm{L}$. Groundwater has a Na+ concentration range from 353 to $832 \mathrm{mg} / \mathrm{L}$ with a median of $525 \mathrm{mg} / \mathrm{L}$, a $\mathrm{Ca}^{2+}$ concentration range from 13 to $34 \mathrm{mg} / \mathrm{L}$ with a median of $17 \mathrm{mg} / \mathrm{L}$ and a $\mathrm{Mg}^{2+}$ concentration range from 7.1 to $58 \mathrm{mg} / \mathrm{L}$ with a median of $12 \mathrm{mg} / \mathrm{L}$. For groundwater anions, $\mathrm{HCO}_{3}{ }^{-}$concentration varies from 281 to $551 \mathrm{mg} / \mathrm{L}$ with a median of $418 \mathrm{mg} / \mathrm{L}, \mathrm{SO}_{4}{ }^{2-}$ concentration varies from 87 to $278 \mathrm{mg} / \mathrm{L}$ with a median of $158 \mathrm{mg} / \mathrm{L}$, and $\mathrm{Cl}^{-}$concentration varies from 110 to $705 \mathrm{mg} / \mathrm{L}$ with a median of $389 \mathrm{mg} / \mathrm{L}$. The chemical types of groundwater are mainly $\mathrm{Na}-\mathrm{Cl}$ (Table A1; Fig. 3).

Total iodine concentration in groundwater ranges from 3 to $1,106 \mu \mathrm{g} / \mathrm{L}$, with an average value of 271 $\mu \mathrm{g} / \mathrm{L}$. More than $48 \%$ of the groundwater samples have an iodine concentration higher than the Chinese $\mathrm{MCL}$ value for iodine in drinking water. As shown in Fig. 1, high iodine groundwater $(>100 \mu \mathrm{g} / \mathrm{L})$ is mainly concentrated toward the end of the flow path and the region III, and presents an increasing trend along the groundwater flow path. The obvious increase occurs in the coastal area, where the groundwater iodine concentration ranges from 110 to $1,110 \mu \mathrm{g} / \mathrm{L}$ (Fig. 2C). lodide concentration ranges from 0.7 to $854 \mu \mathrm{g} / \mathrm{L}$ and is the predominant species in high iodine groundwater (Fig. 2d and A2). lodate and organic iodine range from $<0.1$ to $695 \mu \mathrm{g} / \mathrm{L}$ and from $<0.1$ to $296 \mu \mathrm{g} / \mathrm{L}$, respectively. Groundwater had a $\mathrm{Br}^{-}$ concentration range of $233-2015 \mu \mathrm{g} / \mathrm{L}$ in region III, higher than the range $26-367 \mu \mathrm{g} / \mathrm{L}$ in the region I and 
II. The $\mathrm{Cl} / \mathrm{Br}$ molar ratios of groundwater range widely between 133 and 3,680 . The seawater sample has a $\mathrm{Cl} / \mathrm{Br}$ molar ratio of 1,231 , higher than the average value of seawater (650).

\subsection{Sediment geochemistry}

As shown in Figs. 4 and 5, the lithology and grain size analysis of sediments showed that the aquifer sediment is mainly composed of silty sand and interbedded with silty clay, and thick silty clay (fine particles) was prevalent among the three boreholes. The TOC value in sediments is generally low, with 0.021-0.485 (median: 0.064) \% for borehole BT, 0.023-0.237 (median: 0.07) \% for borehole CZ, 0.0160.765 (median: 0.059 ) \% for borehole $\mathrm{HH}$, and only relatively high value existed near ground surface. The electric conductivity (EC) of sediment suspensions ranged from 99.6 to $934 \mu \mathrm{S} / \mathrm{cm}$ for borehole BT, 176 to $612 \mu \mathrm{S} / \mathrm{cm}$ for borehole $\mathrm{CZ}$, and 310 to $5,680 \mu \mathrm{S} / \mathrm{cm}$ for borehole $\mathrm{HH}$. Element analysis of the sediments indicates that they contains abundant $\mathrm{Fe}_{2} \mathrm{O}_{3}$ and $\mathrm{Al}_{2} \mathrm{O}_{3}$, with 3.1-12 (median: 5.8 ) wt\% and 8.8-17.8 (median: 14.6) wt\% for borehole BT, 2.8-12 (median: 5.8) wt\% and 7.9-18 (median: 14) wt\% for borehole $\mathrm{HH}$, respectively.

The extracted iodine concentration for the three binding states (exchangeable, bound to carbonate, bound to $\mathrm{Fe}_{2} \mathrm{O}_{3}$ ) in the borehole sediments is shown in Table $\mathrm{A} 3$ and $\mathrm{A} 4$. The total iodine concentration extracted from the borehole sediments ranges from 0.053 to $1.7 \mu \mathrm{g} / \mathrm{g}$ for $\mathrm{BT}, 0.089$ to $0.88 \mu \mathrm{g} / \mathrm{g}$ for $\mathrm{CZ}$, and 0.17 to $3 \mu \mathrm{g} / \mathrm{g}$ for $\mathrm{HH}$. The highest extracted iodine concentration in sediments from borehole $\mathrm{HH}$ occurs at a depth of $270-280 \mathrm{~m}$, much higher than other values. Low exchangeable iodine concentrations are observed in boreholes $B T$ and $C Z$, ranging from $<0.001$ to $0.094 \mu \mathrm{g} / \mathrm{g}$ and from 0.024 to $0.066 \mu \mathrm{g} / \mathrm{g}$, respectively. High exchangeable iodine concentration occurs in borehole $\mathrm{HH}$ and ranges from 0.015 to $2.85 \mu \mathrm{g} / \mathrm{g}$. Note that the highest total extracted iodine concentration corresponds to the highest exchangeable iodine. The iodine species analysis indicates the exchangeable iodine is basically iodide. The concentration of iodine binding to carbonates ranges from 0.007 to $0.361 \mu \mathrm{g} / \mathrm{g}$ for borehole BT and 0.005 to $0.289 \mu \mathrm{g} / \mathrm{g}$ for borehole $\mathrm{HH}$. There is no apparent difference in iodine binding to the carbonate phase between the two boreholes. Of the chemically active fractions, abundant iodine is bound to Fe-oxides in the sediments: 0.04 to $1.67 \mu \mathrm{g} / \mathrm{g}$ for borehole BT and 0.073 to $0.49 \mu \mathrm{g} / \mathrm{g}$ for borehole $\mathrm{HH}$.

\subsection{Pore water chemistry}

As shown in Table A5, pore water had a range of $147-34400 \mathrm{mg} / \mathrm{L}$ for $\mathrm{Cl}^{-}$with a median of $959 \mathrm{mg} / \mathrm{L}$, $115-69500 \mu \mathrm{g} / \mathrm{L}$ for $\mathrm{Br}^{-}$with a median of $1300 \mu \mathrm{g} / \mathrm{L}$ and 1.4 to $830 \mu \mathrm{g} / \mathrm{L}$ with a median of $16 \mu \mathrm{g} / \mathrm{L}$ for iodine from the two boreholes. Individually, $\mathrm{Cl}^{-}$concentration of pore water had a range of 147-359 $\mathrm{mg} / \mathrm{L}$ from borehole BT and $4190-34400 \mathrm{mg} / \mathrm{L}$ from borehole $\mathrm{HH}$, presenting an increasing trend toward to Bohai Sea. Similarly, $\mathrm{Br}^{-}$concentration of pore water had a range of $115-779 \mu \mathrm{g} / \mathrm{L}$ from borehole BT and $6580-69500 \mu \mathrm{g} / \mathrm{L}$ from borehole $\mathrm{HH}$. Borehole BT and $\mathrm{HH}$ had pore water iodine concentration ranges of $1.4-132 \mu \mathrm{g} / \mathrm{L}, 4.8-80 \mu \mathrm{g} / \mathrm{L}$ and $3.6-830 \mu \mathrm{g} / \mathrm{L}$, respectively. High iodine concentration of pore water occurred at the specific depth of $150 \mathrm{~m}$ and $280 \mathrm{~m}$ from borehole $\mathrm{HH}$. Pore water samples had a range of $<0.1-11 \mu \mathrm{g} / \mathrm{L}$ with a median of $0.2 \mu \mathrm{g} / \mathrm{L}$ for iodate, $0.1-809 \mu \mathrm{g} / \mathrm{L}$ with a median of $8.3 \mu \mathrm{g} / \mathrm{L}$ for 
iodide and $<0.1-43 \mu \mathrm{g} / \mathrm{L}$ with a median of $3.2 \mu \mathrm{g} / \mathrm{L}$ for organic l, respectively. lodide was the predominant species of I in pore water, coexisting with iodate and organic iodine (Fig. A3).

Pore water had a $\mathrm{Cl} / \mathrm{Br}$ molar ratio range from 590 to 3460 with a median of 1320 and difference existed between two boreholes. The $\mathrm{Cl} / \mathrm{Br}$ molar ratio of pore water changed from 591 to 3460 with a RSD (Relative Standard Deviation) value of 691 for borehole BT, and from 694 to 2010 with a RSD value of 305 for borehole HH (Figs. 4 and 5).

\section{Discussion}

\subsection{Loading of marine iodine on sediment}

Sediments affected by different environment backgrounds (e.g. fluvial, marine) generally have unique geochemical signals (Zhang et al. 1997). This is reflected in the sediments from the two boreholes located different distances from the coastline (Fig. 1; from far to near: BT, HH), showing high salinity sediments from the borehole $\mathrm{HH}$ (Fig. 6). It is worth to note that the concentration of $\mathrm{Cl}^{-}$and $\mathrm{Br}^{-}$in pore water behave similar to sediments' salinity (Table A3). Seawater had a TDS value of $26300 \mathrm{mg} / \mathrm{L}$, with $15500 \mathrm{mg} / \mathrm{L} \mathrm{Cl}, 28400 \mu \mathrm{g} / \mathrm{L} \mathrm{Br}$ (Table A2). It is known that that the $\mathrm{Cl}^{-}$and $\mathrm{Br}^{-}$of seawater present significant enrichment relative to general continental fresh waters (Channer et al. 1997). Trend can be observed in two boreholes that higher $\mathrm{Cl}^{-}$and $\mathrm{Br}^{-}$concentration of pore water as closer to the Bohai Sea. $\mathrm{Cl}^{-}$and $\mathrm{Br}^{-}$are widely used as tracer based on their ideal conservative characteristic (Davis et al. 2004; Cartwright et al. 2006; Alcalá et al. 2008). Generally, they are highly soluble and do not undergo ion exchange and adsorption on minerals, and thus some physical process (mixing or dilution) can change their absolute amount but $\mathrm{Cl} / \mathrm{Br}$ molar ratio. Marine-affected groundwater is considered to exhibit a stable $\mathrm{Cl} / \mathrm{Br}$ molar ratios, equal to or higher than 650 (Davis et al. 2004). In the Borehole $\mathrm{HH}$, the relatively high $\mathrm{Cl}^{-}$and $\mathrm{Br}^{-}$concentration and stable $\mathrm{Cl} / \mathrm{Br}$ molar ratio of pore water is closer to that (1230) of seawater sample in the coast of Bohai Sea, indicating the marine origin of $\mathrm{Cl}^{-}$and $\mathrm{Br}^{-}$(Table A3, Figs. 5 and 6). In the coastal regions of the NCP, the Quaternary strata are comprised of fine-grained fluvial sediments showing high proportion of clay and silt, which are prone to waterlogging and serve as a reservoir of seawater ions (Figs. 5 and 6). According to the paleo-environment reconstruction suggested by Zhang et al. (2005) and Wang and Li (2008), past lakes and marshland could have retained seawater during marine transgression-regression cycles, resulting in a large amount of salinity loaded on the sediments, including $\mathrm{Na}^{+}, \mathrm{Cl}^{-}$, and $\mathrm{Br}^{-}$of marine origin (Kesler et al. 1996; Channer et al. 1997). The Na-Cl type groundwater with high $\mathrm{Br}^{-}$concentration (214 to $2015 \mu \mathrm{g} / \mathrm{L}$ ) and high TDS (1,100 to 2,400 mg/L) in the coastal area was assumed to be the result of salinity leaching from such sediments (Table 1 ; Fig. 3 ). 
Table 1

Phase mole transfers of inverse geochemical modeling (in $\mathrm{mol} / \mathrm{L}$ )

\begin{tabular}{|c|c|c|c|c|c|}
\hline \multirow{4}{*}{$\begin{array}{l}\text { Mole } \\
\text { transfers }\end{array}$} & \multirow{4}{*}{$\begin{array}{l}\text { Initial solution } \\
\text { Final solutions }\end{array}$} & \multicolumn{4}{|c|}{ 区NCP16-16 I:115 ( $\mu \mathrm{g} / \mathrm{L})$ TDS:864 (mg/L) } \\
\hline & & \multirow{2}{*}{$\begin{array}{l}\text { खNCP16-03 } \\
\text { l: } 198 \\
(\mu \mathrm{g} / \mathrm{L})\end{array}$} & 『NCP16-05 & खCZ-10 & बCZ-3 \\
\hline & & & \multirow{2}{*}{$\begin{array}{l}\text { l: } 367(\mu \mathrm{g} / \mathrm{L}) \\
\text { TDS: } 1250 \\
(\mathrm{mg} / \mathrm{L})\end{array}$} & \multirow{2}{*}{$\begin{array}{l}\text { I: } 771(\mu \mathrm{g} / \mathrm{L}) \\
\text { TDS: } 1820 \\
(\mathrm{mg} / \mathrm{L})\end{array}$} & \multirow{2}{*}{$\begin{array}{l}\text { I: } 1110 \\
\text { ( } \mu \mathrm{g} / \mathrm{L}) \\
\text { TDS: } 1800 \\
(\mathrm{mg} / \mathrm{L})\end{array}$} \\
\hline & & $\begin{array}{l}\text { TDS: } 892 \\
\text { (mg/L) }\end{array}$ & & & \\
\hline Albite & $\mathrm{NaAlSi}_{3} \mathrm{O}_{8}$ & $-8.73 E-04$ & 4.48E-03 & $-9.39 \mathrm{E}-04$ & 7.24E-03 \\
\hline Calcite & $\mathrm{CaCO}_{3}$ & $-3.19 \mathrm{E}-02$ & 2.89E-02 & $1.18 \mathrm{E}-02$ & 8.58E-02 \\
\hline Fluorite & $\mathrm{CaF}_{2}$ & $9.18 \mathrm{E}-04$ & $2.67 \mathrm{E}-04$ & $5.16 \mathrm{E}-04$ & $5.15 \mathrm{E}-04$ \\
\hline Halite & $\mathrm{NaCl}$ & 5.03E-02 & $2.58 \mathrm{E}-01$ & $-9.33 E-04$ & $-1.06 \mathrm{E}-03$ \\
\hline Kaolinite & $\mathrm{Al}_{2} \mathrm{Si}_{2} \mathrm{O}_{5}(\mathrm{OH})_{4}$ & $-1.05 E-03$ & 7.65E-03 & $-9.61 E-04$ & 1.13E-02 \\
\hline Chlorite(14A) & $\mathrm{Mg}_{5} \mathrm{Al}_{2} \mathrm{Si}_{3} \mathrm{O}_{10}(\mathrm{OH})_{8}$ & $1.78 \mathrm{E}-03$ & $-1.02 \mathrm{E}-02$ & $1.38 \mathrm{E}-03$ & $-1.50 \mathrm{E}-02$ \\
\hline K-feldspar & $\mathrm{KAISi}_{3} \mathrm{O}_{8}$ & $-5.96 \mathrm{E}-04$ & $6.03 \mathrm{E}-04$ & $1.01 \mathrm{E}-04$ & $9.91 \mathrm{E}-05$ \\
\hline $\mathrm{CaX}_{2}$ & $\mathrm{CaX}_{2}$ & 4.37E-03 & $-5.44 \mathrm{E}-02$ & $-5.34 \mathrm{E}-02$ & $-1.18 \mathrm{E}-01$ \\
\hline $\mathrm{MgX}_{2}$ & $\mathrm{MgX}_{2}$ & - & $5.44 \mathrm{E}-02$ & - & $8.18 \mathrm{E}-02$ \\
\hline $\mathrm{NaX}$ & $\mathrm{NaX}$ & $-8.75 E-03$ & - & 1.07E-01 & 7.15E-02 \\
\hline Gypsum & $\mathrm{CaSO}_{4}: 2 \mathrm{H}_{2} \mathrm{O}$ & $3.31 \mathrm{E}-02$ & $3.27 \mathrm{E}-02$ & $4.86 \mathrm{E}-02$ & 3.88E-02 \\
\hline $\mathrm{CO}_{2}(\mathrm{~g})$ & $\mathrm{CO}_{2}$ & $-5.75 E-02$ & $-1.20 \mathrm{E}-01$ & 7.45E-02 & - \\
\hline
\end{tabular}

The ocean is a repository for iodine, which is especially present in marine organisms. These iodine-rich marine organisms are most likely to accumulate in sediments affected by seawater during marine transgressions and their degradation during the long-term burial would release iodine (Xue et al. 2019b). As a result of strong organic matter degradation, low levels of TOC and high concentration of inorganic iodine species can be observed in sediment and groundwater, respectively (Tables S4 and S5; Fig. 4). It is worth to note that the highest total inorganic-bound iodine occurred at the depth of 270-290 m, corresponding to the horizon of Bohai transgression reported by Lin and Dai (2012). Similar to the extracted inorganic-bound iodine in sediment, the iodine concentration in pore water exhibited relatively high from borehole $\mathrm{HH}$, with the super high iodine concentration corresponding to the horizons of Bohai and Huanghua transgression (270-290 m and 130-165 m). These phenomena indicated the input of 
iodine to the groundwater system may be related to Quaternary marine transgressions accompanied by paleo-climate change and sea level fluctuation. The marine transgression and regression events during the Quaternary have been determined based on dozens of boreholes in the coastal area of the NCP, and marine-affected sediments have accumulated in the study area (Lin and Dai 2012; Yao et al. 2012; Yi et al. 2012).

Inorganic-bound iodine from sediment generally occurs in three main forms: exchangeable iodine, iodine bound to carbonate, and iodine bound to Fe-oxides (Yamaguchi et al. 2010; Xu et al. 2015). Significant differences were observed with respect to extracted iodine concentration between the two boreholes. Feoxides was believed as the important supporter of solid iodine from borehole BT (Fig. 5). However, for the borehole $\mathrm{HH}$, exchangeable iodine was the main occurrence state in sediments, with the highest proportion of $92 \%$ in total extracted iodine (Fig. 6). Components in the exchangeable state are generally adhered to the surface of minerals, such as metal (hydr)oxides which are abundant in sediment of the $\mathrm{NCP}$, and can migrate relatively easily during adsorption/desorption process. This indicates that marineaffected sediments held considerable iodine easy to migrate, although some of iodine bound to Feoxides.

\subsection{Controls of adsorption/desorption on iodine enrichment in groundwater}

\subsubsection{Insight from the relationship between iodine and $\mathrm{Cl}^{-}$, $\mathrm{Br}$}

lodine belongs to the halogen group, which occupy group 17 of the periodic table and are characterized by an $\mathrm{S}^{2} \mathrm{P}^{5}$ outer electron shell configuration enabling their characteristic ability to form halide anions in ionically bonded salts. $\mathrm{F}, \mathrm{Cl}, \mathrm{Br}$, and I have some basic hydro-geochemical similarities and though exhibit marked differences in behavior of mobilization and enrichment in sediments and their fluids. In comparison with $\mathrm{F}$, the heavier halogens $(\mathrm{Cl}, \mathrm{Br}$, and I) all have similarly strong incompatibilities in the Earth's environment (similar to K or Nb; Kendrick et al. 2013) and high solubilities in aqueous fluids. The heavy halogens are however fractionated from each other by the evaporation of seawater beyond the point of halite saturation, because $\mathrm{Br}$ and I are incompatible in halite, and $\mathrm{Cl}^{-}$substitutes for the $\mathrm{OH}$-group in many hydrous minerals more easily than the larger $\mathrm{Br}$ and I ions (Kendrick 2017). In this study, the relative stable $\mathrm{Cl} / \mathrm{Br}$ molar ratio of pore water excluded the effect of evaporation beyond the point of halite saturation. Although the occurrence of some evaporation effects, the residual paleo-seawater from marine transgression mostly undergone some dilution and desalination, according their lower absolute concentration of $\mathrm{Cl}^{-}$. Whether evaporative concentration or dilution, halides changes in absolute concentration, not relative concentration.

$\mathrm{Br}$ is a typical marine element and also found in organic compounds, similar to I. Previous studies stressed that organic activity increased I and $\mathrm{Br}$ from meteoric water but could not change the $\mathrm{Cl}^{-}$ 
concentration (Biester et al. 2006). Detailed geochemical studies have shown that organo-Br compounds may be present in rich in organic matter or coastal environment, with $\mathrm{Br}$ possibly linked to amine groups (Vassilev et al. 2000; Yudovich and Ketris 2006). This reflected that $\mathrm{Br}$ concentration may be variable during the process of organic matter decomposition. However, the obvious enrichment of iodine relative to bromine may indicate a weak role from biological activity on iodine, at least from this study's data. In addition, biological activity in deep sediments was limited by low carbon sources (Table A3 and A4).

In addition to organic processes, some physicochemical processes are likely to affected element migration and enrichment in groundwater system, such as adsorption and desorption processes (Mai et al. 2014). As mentioned above, $\mathrm{Cl}^{-}$and $\mathrm{Br}^{-}$are generally observed as conserved anions and may not be controlled by adsorption and desorption processes. As shown in Fig. 2c, iodide dominated the iodine form in groundwater, which can adsorb onto mineral surface and exhibit strong migration ability (Nagata et al. 2009). This suggested that the relationship between iodine and $\mathrm{Cl}^{-}$or $\mathrm{Br}^{-}$might demonstrate the adsorption and desorption process in the geochemical evolution of groundwater. $\mathrm{l} / \mathrm{Cl}$ and $\mathrm{l} / \mathrm{Br}$ weight ratio of seawater were relative low, and thereby iodine enrichment relative to $\mathrm{Cl}^{-}$and $\mathrm{Br}^{-}$does not occur in pore water and groundwater only under the marine influence. Due to the process of adsorption/desorption, high $\mathrm{l} / \mathrm{Cl}$ and $\mathrm{l} / \mathrm{Br}$ weight ratios can be observed in high iodine groundwater and pore water. The wide distribution of high iodine groundwater in coastal region indicates that iodine enrichment may be associated with marine influence. From the vertical distribution of iodine (mainly refers to sediment and pore water iodine at different depths), plaeo- transgression events may be the main contributors to iodine enrichment. Thus, a theoretical iodine enrichment mechanism can be proposed: In the events of paleo- transgression, iodine in seawater was adsorbed on sediments and subsequently long-term adsorption/desorption process resulted in iodine enrichment of groundwater system.

\subsubsection{Insight from geochemical characteristics}

As mentioned above, three main occurrence of iodine (exchangeable, carbonate and Fe-oxides associated) showed that inorganic sedimentary iodine accumulated in the groundwater system, which may act as origin of high iodine groundwater and pore water. Calcium carbonates, which are widely found in sediments, are present as several polymorphs, including calcite, aragonite, and vaterite, as well as amorphous phases (Kato et al. 2002). Elevated levels of iodine have been documented in both natural and synthetic calcium carbonates and are considered to be present mainly as the $\mathrm{IO}_{3}$ group substituting for $\mathrm{CO}_{3}$ (Podder et al. 2017). The mobility of iodine in the form of lattice structure is likely to be limited, which also can be reflected by the poor correlation between $\mathrm{Ca}$ and iodine in groundwater. Fe-oxides are generally supposed to be adsorbed by large surface areas available for anions, especially for iodate (Nagata and Fukushi 2010). In the borehole BT far from coastline, Fe-oxides were the major holder for sedimentary iodine. Along the groundwater flowpath, the evolution of groundwater environment to reducing environment supports the reductive dissolution of iron oxides. Therefore, the reductive dissolution of iron oxides will inevitably release the loaded iodine, which is responsible for the enrichment of iodine in groundwater with iodine concentration below $200 \mu \mathrm{g} / \mathrm{L}$ (Fig. 7a). It was interesting to note 
that exchangeable iodine presented high concentration and accounted for the most (up to 92\%) of total inorganic iodine from the borehole $\mathrm{HH}$, where the groundwater iodine concentration higher than $200 \mu \mathrm{g} / \mathrm{L}$. And even, pore water from the borehole $\mathrm{HH}$ also had a high iodine concentration up to $830 \mu \mathrm{g} / \mathrm{L}$. This indicates that it should be desorption of exchangeable iodine from sediments controlling high levels of iodine in groundwater and pore water.

As the main control process of high iodine groundwater, adsorption/desorption are mainly affected by $\mathrm{pH}$ and ionic strength of groundwater (El-Bayaa et al. 2009; Hao et al. 2019). According to some studies (Ledin et al. 1993; Venema et al. 1996; Nagata et al. 2009), pH ZPC (ZPC: zero point of charge) for common minerals, such as hydrous ferric oxide, hematite, $\mathrm{a}-\mathrm{Al}(\mathrm{OH})_{3}$, were almost between 7.8 and 8.2, corresponding to the range of high iodine groundwater (Fig. 2a). lodide can be adsorbed onto minerals under the groundwater $\mathrm{pH}<\mathrm{pH}_{\mathrm{ZPC}}$, but desorbed from minerals under the groundwater $\mathrm{pH}>\mathrm{pH} \mathrm{ZPC}_{\mathrm{ZC}}$. In general, solution ionic strength can affect mineral surface reactivity, and in turn, impact trace element adsorption. The increase in TDS in groundwater may result in impacts that act on exchangeable iodine desorbed from minerals. According to recent research, two explanations are given for the effects of solution ionic strength on mineral reactivity: competitive adsorption of solution electrolytes (e.g. $\mathrm{Na}^{+}$, $\mathrm{HCO}_{3}{ }^{-}$) with trace elements for adsorption onto minerals surface sites (Coppin et al. 2002; Bradl 2004), and weakening of the mineral surface electrostatic field leading to a reduced capacity for trace element adsorption (Bohn et al. 2002). As the most mobile species of iodine, iodide might be affected by both processes. Therefore, high solution ionic strength may promote the release of iodide adsorbed onto sedimentary minerals when high salinity sediments are leached by groundwater. The good linear correlation $\left(R^{2}=0.70\right)$ between iodine and TDS in groundwater indicated that strong ion exchange play a critical role in the high iodine groundwater (Fig. 7b).

\subsubsection{Insight from inverse geochemical modeling}

To further understand the effect of adsorption and desorption on the chemical composition of groundwater, inverse modeling was used to describe quantitatively the water-sediment interaction along the groundwater flow path based on PHREEQC. According to previous studies conducted by Xing et al. (2013), major mineral phases included albite, fluorite, halite, gypsum, K-feldspar, calcite, kaolinite, Chlorite $(14 \mathrm{~A})$, and $\mathrm{CO}_{2}(\mathrm{~g})$ in aquifer sediments of the NCP. As an important reaction of groundwater chemistry evolution, ion exchange was generally characterized by cation exchange between $\mathrm{Ca}^{2+}\left(\mathrm{Mg}^{2+}\right)$ and $\mathrm{Na}^{+}$and involved in this modeling. Initial groundwater sample was selected from the border of coastal and central region, with iodine concentration of $115 \mu \mathrm{g} / \mathrm{L}$. Final groundwater samples were selected from coastal region, with iodine concentration of $198 \mu \mathrm{g} / \mathrm{L}, 367 \mu \mathrm{g} / \mathrm{L}, 771 \mu \mathrm{g} / \mathrm{L}, 1110 \mu \mathrm{g} / \mathrm{L}$. The results were showed in Table 1 and Fig. 8.

Although some minerals dissolution/precipitation occurred in coastal areas, the control of ion exchange on iodine exhibited more prominently. The aquifer sediments were composed of medium and fine sand in central region, and gradually finer in coastal region companied with clay mineral proportion (Figs. 4 and 5). The sediment of fine particles also supports more ion adsorption sites, such as for $\mathrm{Na}^{+}, \mathrm{Ca}^{2+}$ and 
$\mathrm{Mg}^{2+}$. High ratios of $\mathrm{Na} / \mathrm{Cl}$ would be supposed to arise from ion exchange between adsorbed $\mathrm{Na}^{+}$and $\mathrm{Ca}^{2+}$ and $\mathrm{Mg}^{2+}$ from solution, as following equation (Fig. A4):

$\mathrm{Na}_{2}$-sediment $+\left(\mathrm{Ca}^{2+}+\mathrm{Mg}^{2+}\right)$ (groundwater $)=\left(\mathrm{Ca}^{2+}+\mathrm{Mg}^{2+}\right)$-sediment $+2 \mathrm{Na}^{+}$

In addition to cation exchange, competitive adsorption of anions is also very common in aqueous environment (Violante 2013; Yang et al. 2015). As major anions in groundwater, both $\mathrm{HCO}_{3}{ }^{-}$and $\mathrm{SO}_{4}{ }^{2-}$ can adsorb onto minerals and present the competitive adsorption behavior with iodine. Due to considerable amounts of exchangeable iodine $\left(\mathrm{I}^{-}\right)$on sediment, the competitive adsorption among anions would cause the adsorbed iodide to be released into groundwater, as following equation:

$\mathrm{I}_{2}$-sediment $+\left(2 \mathrm{HCO}_{3}{ }^{-}+\mathrm{SO}_{4}{ }^{2-}\right)($ groundwater $)=\left(2 \mathrm{HCO}_{3}{ }^{-}+\mathrm{SO}_{4}{ }^{2-}\right)$-sediment $+2 \mathrm{I}^{-}$

As shown in Fig. 8, the increase of iodine concentration in groundwater was accompanied by elevated proportion of ion exchange on water-sediment interaction, stressed again that strong ion exchange could facilitate the desorption of iodide adsorbed on sediment.

\section{Conclusions}

A total of 43 groundwater samples, one seawater sample, 107 sediment samples and 111 pore water samples were collected from the North China Plain to investigate iodine enrichment in the groundwater system. Groundwater iodine concentration increased along the groundwater flow path from Taihang Mountain to Bohai Bay and increased greatly around the coastal area, with an overall range from 3 to $1,110 \mu \mathrm{g} / \mathrm{L}$. More than $48 \%$ of the groundwater samples taken had an iodine concentration higher than the value set by the Chinese government as the drinking water standard $(100 \mu \mathrm{g} / \mathrm{L})$. Active iodine extracted from sediments from two long boreholes included exchangeable, carbonate associated, and Feoxides associated fractions. Carbonates and Fe-oxides serve to store iodine, and no large differences in two fractions were observed among the three boreholes. In contrast, exchangeable iodine was relatively low in sediments from boreholes BT (inland) but high in borehole HH (coastal) (up to $2.85 \mu \mathrm{g} / \mathrm{g}$ ). Past marine transgression events have resulted in a large amount of marine iodine stored in sediments, likely present as exchangeable iodide adsorbed onto mineral surface. As these marine-affected sediments leach, the exchangeable iodine, existing as iodide adsorbed onto sediment, is desorbed and released into pore water and groundwater. This mechanism is responsible for the widespread distribution of high iodine groundwater in the coastal area of the North China Plain.

\section{Declarations}

Acknowledgements The author gratefully acknowledges the School of Environmental Studies and State Key Laboratory of Biogeology and Environmental Geology, China University of Geosciences, and Yangtze River Basin Ecological Environment Monitoring and Scientific Research Center, Yangtze River Basin 
Ecological Environment Supervision and Administration Bureau, Ministry of Ecological Environment for providing facilities while carrying out experimental.

Funding The research work was financially supported by the National Natural Science Foundation of China (No. 41521001, 41502230 and 41772255), the 111 Program (The State Administration of Foreign Experts Affairs \& the Ministry of Education of China Grant No. B18049), and the Fundamental Research Funds for the Central Universities, China University of Geosciences (Wuhan) (No. CUGGC07).

Availability of data and materials All data generated or analysed during the this study are included in this published article and its supplementary information files.

Author contributions Xiaobin Xue - main author of the manuscript and conducted the experiments Xianjun Xie - designed the problem, analysis of data and manuscript writing Junxia Li, Yuting Wang and Yanxin Wang - provide work facilities in their respective laboratories and manuscript writing

Ethical approval and consent to participate Not applicable

Consent for publication Not applicable

Competing interest The authors declare no competing interests.

\section{References}

1. Alcalá $\mathrm{F}$, Custodio $\mathrm{E}$ (2008) Using the $\mathrm{Cl} / \mathrm{Br}$ ratio as a tracer to identify the origin of salinity in aquifers in Spain and Portugal. J Hydrol 359: 189-207

2. Ar Gall E, Küpper F, Kloareg B (2005) A survey of iodine content in Laminaria digitata. Bot. Mar. 47: 30-37

3. Biester H, Selimovic D, Hemmerich S, Petri M (2006) Halogens in pore water of peat bogs-the role of peat decomposition and dissolved organic matter. Biogeosciences 3(1): 53-64

4. Bohn H, Myer R, O'Connor G (2002) Soil Chemistry. John Wiley \& Sons

5. Bradl H (2004) Adsorption of heavy metal ions on soils and soils constituents. J Colloid Interface Sci 277: $1-18$

6. Cao G, Zheng C, Scanlon B, Liu J, Li W (2013) Use of flow modeling to assess sustainability of groundwater resources in the North China Plain. Water Resour Res 49: 159-175

7. Cartwright I, Weaver T, Fifield L (2006) Cl/Br ratios and environmental isotopes indicators of recharge variability and groundwater flow: An example from the southeast Murray Basin: Australia. Chem Geol 231: $38-56$

8. Channer D, Ronde C, Spooner E (1997) The $\mathrm{Cl}^{-}-\mathrm{Br}^{-}-\mathrm{I}^{-}$composition of $~ 3.23$ Ga modified seawater: implications for the geological evolution of ocean halide chemistry. Earth Planet Sc Lett 150 (3-4): 
325-335

9. Chen Z, Qi J, Xu J, Xu J, Ye H, Nan Y (2003) Paleoclimatic interpretation of the past 30 ka from isotopic studies of the deep confined aquifer of the North China plain. Appl Geochem18: 997-1009

10. Coppin F, Berger G, Bauer A, Castet S, Loubet M (2002) Sorption of lanthanides on smectite and kaolinite. Chem Geol 182: 57-68

11. Davis S, Fabryka-Martin J, Wolfsberg L (2004) Variations of bromide in potable groundwater in the United States. Ground Water 42 (6): 902-909

12. de la Cuesta J, Manley S (2009) lodine assimilation by marine diatoms and other phytoplankton in nitrate-replete conditions. Limnol Ocean 54: 1653-1664

13. El-Bayaa A, Badawy N, AlKhalik E (2009) Effect of ionic strength on the adsorption of copper and chromium ions by vermiculite pure clay mineral. J Hazard Mater 170: 1204-1209

14. Fuge R, Johnson C (2015) lodine and human health, the role of environmental geochemistry and diet, a review. Appl Geochem 63: 282-302

15. Fuge R, Johnson C (1986) The geochemistry of iodine - a review. Environ Geochem Health 8: 31-54

16. GB/T 19380-2016. Definition and Demarcation of Water-Borne lodine-Excess Areas and lodineExcess Endemial Areas. The Ministry of Health, China (in Chinese with English abstract) 1-2

17. Guo H, Zhang Z, Cheng G, Li W, Li T, Jiao J (2015) Groundwater-derived land subsidence in the north China plain. Environ Earth Sci 74: 1415-1427

18. Hao W, Flynn S, Kashiwabara T, Alam M, Bandara S, Swaren L, Robbins L, Alessi D, Konhauser K (2019) The impact of ionic strength on the proton reactivity of clay minerals. Chem Geol 529: 119294

19. Hou X, Fogh C, Andersson K, Dahlgaard H, Nielsen S, (2003) lodine-129 and Caesium-137 in Chernobyl contaminated soil and their chemical fractionation. Sci Total Environ 308: 97-109

20. Johnson C (2003) Database of the lodine Content of Soils Populated with Data from Published Literature. British Geological Survey Report CR/03/004N

21. Kassim I, Moloney G, Busili A, Nur A, Paron P, Jooste P, Gadain H, Seal A (2014) lodine intake in Somalia is excessive and associated with the source of household drinking water. J Nutr 144: 375381

22. Kato T, Sugawara A, Hosoda N, (2002) Calcium carbonate-organic hybrid materials. Adv Mater 14: 869-877

23. Kendrick M, Arculus R, Burnard P, Honda M (2013) Quantifying brine assimilation by submarine magmas: examples from the Galápagos Spreading Centre and Lau Basin. Geochim Cosmochim Acta 123: 150-165

24. Kesler S, Martini A, Appold M, Walter L, Huston T (1996) Na-Cl-Br systematics of fluid inclusions from Mississippi Valley-type deposits, Appalachian Basin: constraints on solute origin and migration paths. Geochim Cosmochim Acta 60(2): 225-233 
25. Kreuzer A, von Rohden C, Friedrich R, Chen Z, Shi J, Hajdas I, Kipfer R, Aeschbach-Hertig W (2009) A record of temperature and monsoon intensity over the past $40 \mathrm{kyr}$ from groundwater in the North China Plain. Chem Geol 259: 168-180

26. Ledin A, Karlsson S, Allard B (1993) Effects of pH, ionic strength and a fulvic acid on size distribution and surface charge of colloidal quartz and hematite. Applied Geochemistry 8(4): 409-414 https://doi.org/10.1016/0883-2927(93)90009-6

27. Li J, Zhou H, Qian K, Xie X, Xue X, Yang Y, Wang Y (2017) Fluoride and iodine enrichment in groundwater of North China Plain: evidences from speciation analysis and geochemical modeling. Sci Total Environ 598: 239-248

28. Lin J, Dai L (2012) Quaternary marine transgressions in eastern China. J Palaeogeogr 1(2): 105-125

29. Mai N, Postma D, Trang P, Jessen S, Viet P, Larsen F (2014) Adsorption and desorption of arsenic to aquifer sediment on the Red River floodplain at Nam Du, Vietnam. Geochim Cosmochim Acta 142: $587-600$

30. Moore R, Pearce C, Morad J, Chaterjee S, Levitskaia T, Asmussen R, Lawter A, Neeway J, Qafoku N, Rigali M, Saslow S, Szecsody J, Thallapally P, Wang G, Freedman V (2020) lodine immobilization by materials through sorption and redox-drived processes: A literature review. Sci Total Environ 716: 132820

31. Muramatsu Y, Wedepohl K (1998) The distribution of iodine in the earth's ctust. Chem Geol 147: 201216

32. Nagata T, Fukushi K (2010) Prediction of iodate adsorption and surface speciation on oxides by surface complexation modeling. Geochim Cosmochim Acta 74: 6000-6013

33. Nagata T, Fukushi K, Takahashi Y (2009) Prediction of iodide adsorption on oxides by surface complexation modeling with spectroscopic confirmation. J Colloid Interf Sci. 332: 309-316

34. Podder J, Lin J, Sun W, Botis S, Tse J, Chen N, Hu Y, Li D, Seaman J, Pan Y (2017) lodate in calcite and vaterite: Insights from synchrotron $\mathrm{X}$-ray absorption spectroscopy and first-principles calculations. Geochim Cosmochim Acta 198: 218-228

35. Razafindratsima S, Peron O, Piscitelli A, Gegout C, Schneider V, Barbecot F, Giffaut E, Robinet J, Le Cointe P, Montavon G (2015) Transport properties of iodide in a sandy aquifer: Hydrogeological modeling and field tracer tests. J Hydrol 520: 61-68

36. Teessier A, Canpbell P, Bisson M (1979) Sequential extraction procedure for the speciation of particulate trace metals. Anal Chem 51(7): 844-851

37. Truex M, Lee B, Johnson C, Qafoku N, Szecsody J, Kyle J, Tfaily M, Snyder M, Cantrell K, Saunders D (2017) Conceptual Model of lodine Behavior in the Subsurface at the Hanford Site. PNNL-24709 Rev 2, RPT-DVZ-AFRI-030, Rev 2, Pacific Northwest National Laboratory Richland, WA, USA

38. Vassilev S, Eskenazy G, Vassileva C (2000) Contents, modes of occurrence and origin of chlorine and bromine in coal. Fuel 79(8): 903-921 https://doi.org/10.1016/s0016-2361(99)00236-7

39. Venema P, Hiemstra T, Van Riemsdijk W (1996) J Colloid Interface Sci 181: 45 
40. Voutchkova D, Ernstsen V, Hansen B, Sørensen B, Zhang C, Kristiansen S (2014) Assessment of spatial variation in drinking water iodine and its implications for dietary intake: a new conceptual model for Denmark. Sci Total Environ 493: 432-444

41. Violante A (2013) Chapter three - Elucidating mechanisms of competitive sorption at the mineral/water interface. Advances in Argronomy 118: 111-176

42. Wang Y, Li H (2008) Initial formation and Mesozoic tectonic exhumation of an intracontinental tectonic belt of the northern part of the Taihang Mountain belt, eastern Asia. J Geol 116: 155-172

43. Wang Y, Zheng C, Ma R (2018) Review: Safe and sustainable groundwater supply in China. Hydrogeol J 26: 1301-1324

44. Wu C, Xu Q, Zhang X, Ma Y (1996) Palaeochannels on the North China Plain: types and distributions. Geomorphol. 18: 5-14

45. Xing L, Guo H, Zhan Y (2013) Groundwater hydrochemical characteristics and processes along flow paths in the North China Plain. Journal of Asian Earth Sciences 70-71: 250-264

46. Xu C, Kaplan D, Zhang S, Athon M, Ho Y, Li H, Yeager C, Schwehr K, Grandbois R, Wellman D, Santschi P (2015) Radioiodine sorption/desorption and speciation transformation by subsurface sediments from the Hanford Site. J Environ Radioact 139: 43-55

47. Xue X, Li J, Xie X, Qian K, Wang Y (2019a) Impacts of sediment compaction on iodine enrichment in deep aquifers of the North China Plain. Water Res 159: 480-489

48. Xue X, Li J, Xie X, Wang Y, Tian X, Chi X, Wang Y (2019b) Effects of depositional environment and organic matter degradation on the enrichment and mobilization of iodine in the groundwater of the North China Plain. Sci Total Environ 686: 50-62

49. Yamaguchi N, Nakano M, Takamatsu R, Tanida H (2010) Inorganic iodine incorporation into soil organic matter: evidence from iodine K-edge X-ray absorption near-edge structure. J Environ Radioact 101: 451-457

50. Yang G, Liu Y, Song S (2015) Competitive adsorption of As(v) with co-existing ions on porous hematite in aqueous solutions. J Environm Chem Eng 3(3): 1497-1503

51. Yao Z, Guo Z, Xiao G, Wang Q, Shi X, Wang X (2012) Sedimentary history of the western Bohai coastal plain since the late Pliocene: implications on tectonic, climate and sea-level changes. J Asian Earth Sci 54-55: 192-202

52. Yi L, Yu H, Ortiz J, Xu X, Qiang X, Huang H, Shi X, Deng C (2012) A reconstruction of late Pleistocene relative sea level in the south Bohai Sea, China, based on sediment grain-size analysis. Sediment Geol 281: 88-100

53. Yudovich Y, Ketris M (2006) Chlorine in coal: A review. Int J Coal Geol 67(1-2): 127-144. https://doi.org/10.1016/j.coal.2005.09.004

54. Zhang E, Wang Y, Qian Y, Ma T, Zhang D, Zhan H, Zhang Z, Fei Y, Wang S (2013 lodine in groundwater of the North China Plain: Spatial patterns and hydrogeochemical processes of enrichment. Journal of Geochemical Exploration 135: 40-53 
55. Zhang E, Zhang F, Qian Y, Ye N, Gong J, Wang Y (2010) The distribution of high iodine groundwater in typical areas of China and its inspiration (in Chinese with English abstract). Geol China 37: 797802

56. Zhang Z, Shi D, Ren F, Yin Z, Sun J, Zhang C (1997) Evolution of quaternary groundwater system in north China plain Sci China (Series D) 40 (3): 276-283

57. Zhang Z, Shen Z, Xue Y, Ren F, Shi D, Yin Z, Zhong Z, Sun X (2000) Evolution of Groundwater and Environment in the North China Plain. Geological Publish House Beijing, China (in Chinese)

58. Zhang Z (2005) Groundwater in the Vast North China Plain [in Chinese]. Chin J Nature 27 (6): 311 315

\section{Figures}

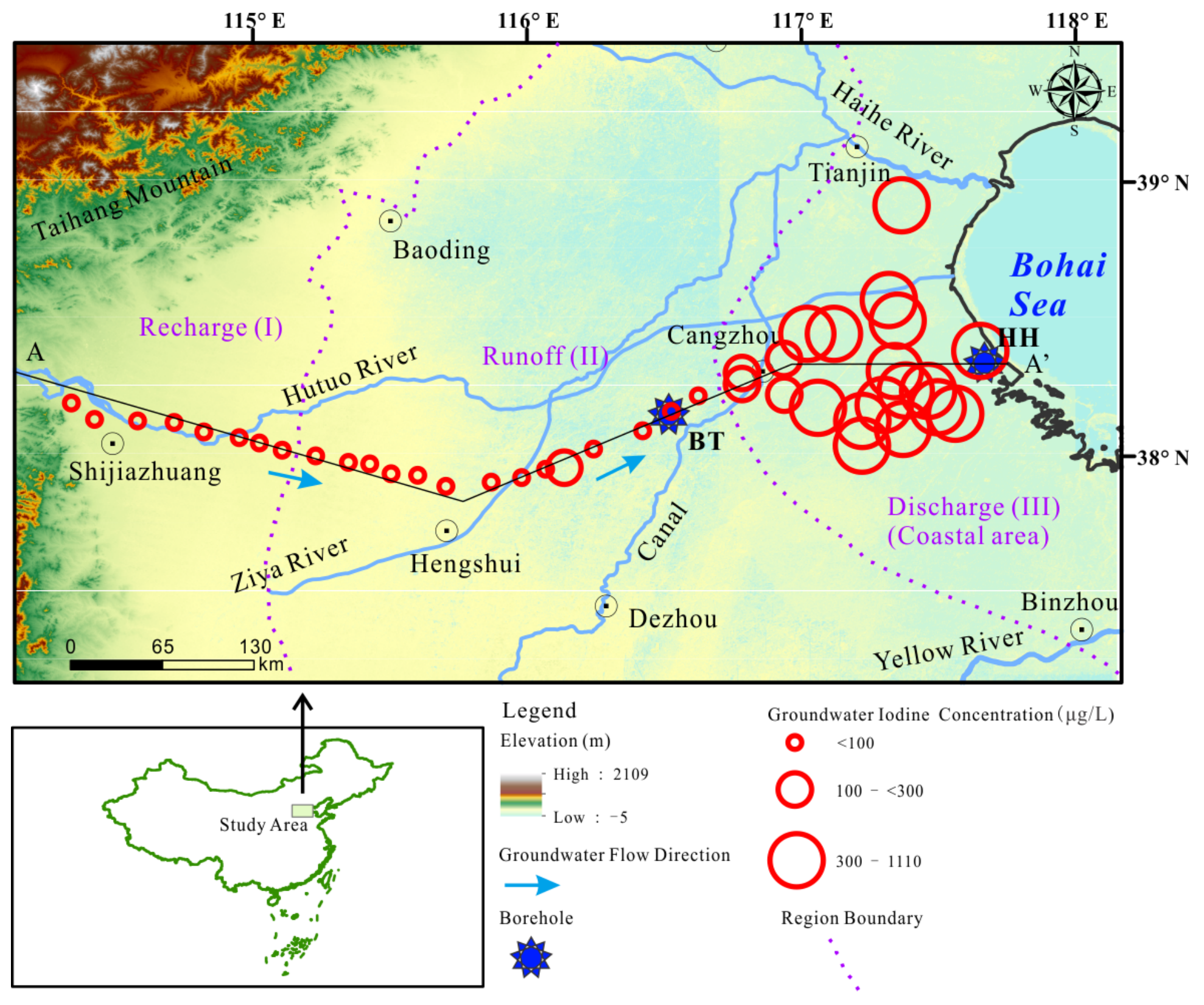


Sampling location Final Revison
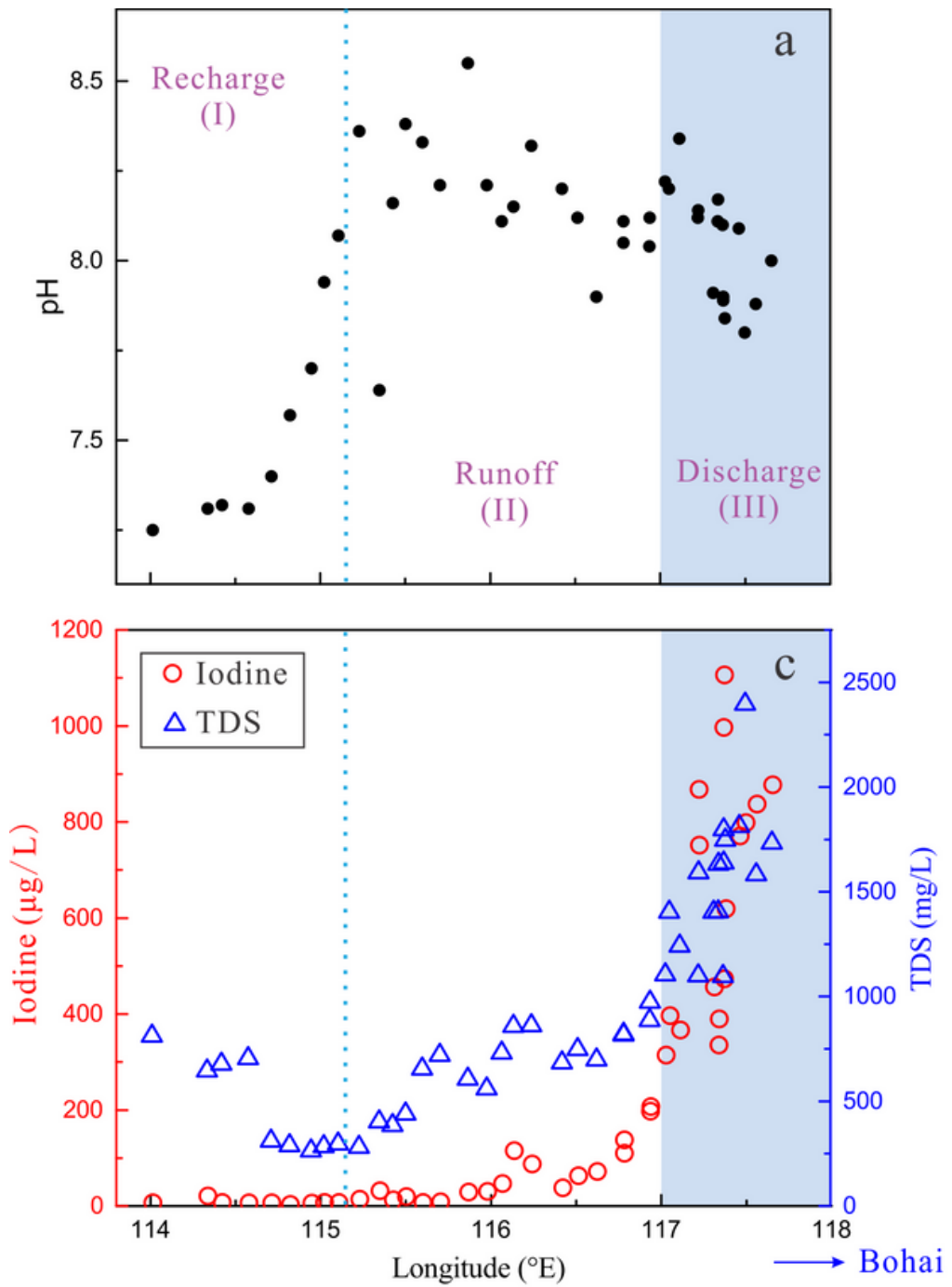
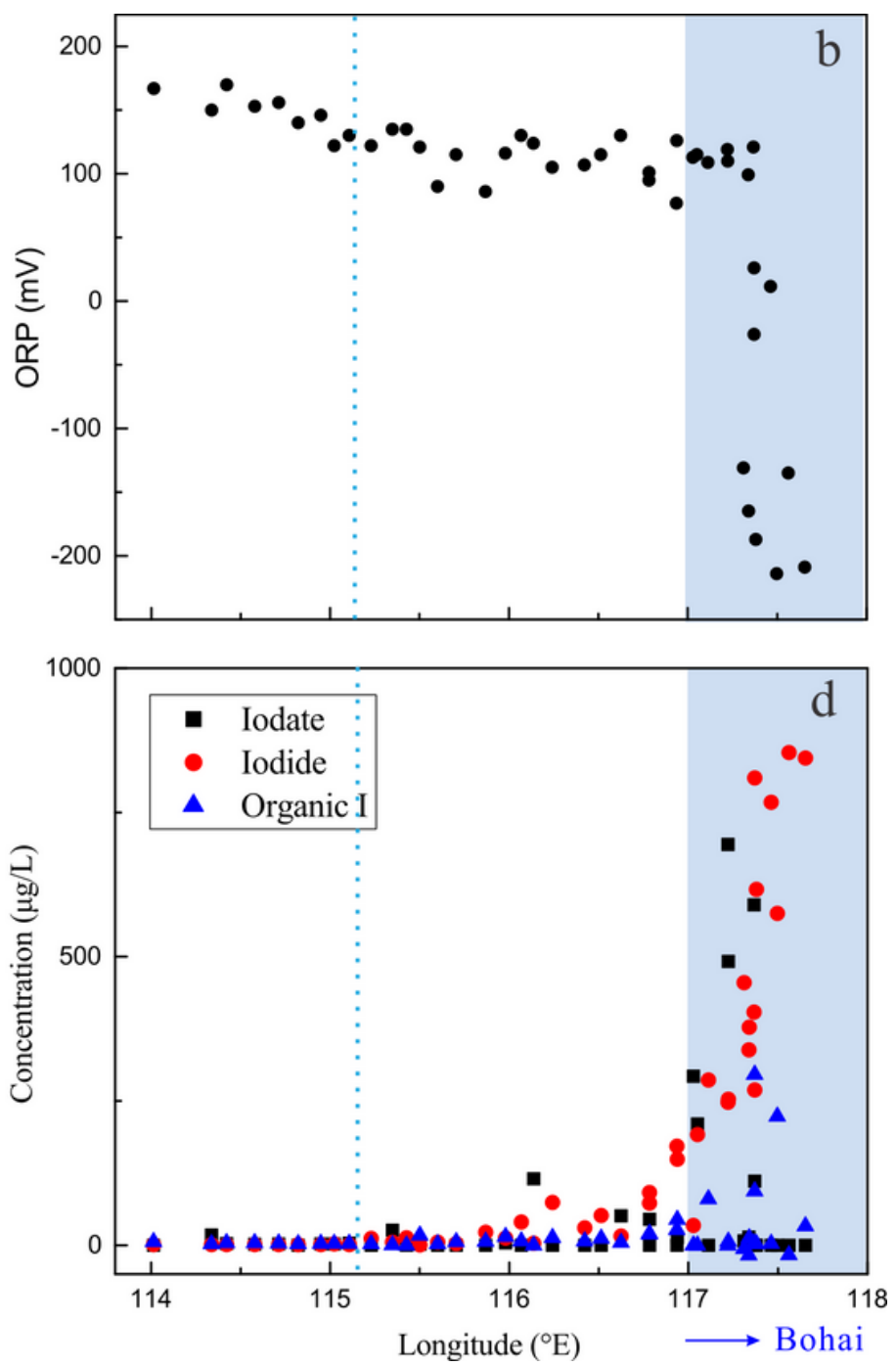

Figure 2

Evolution 


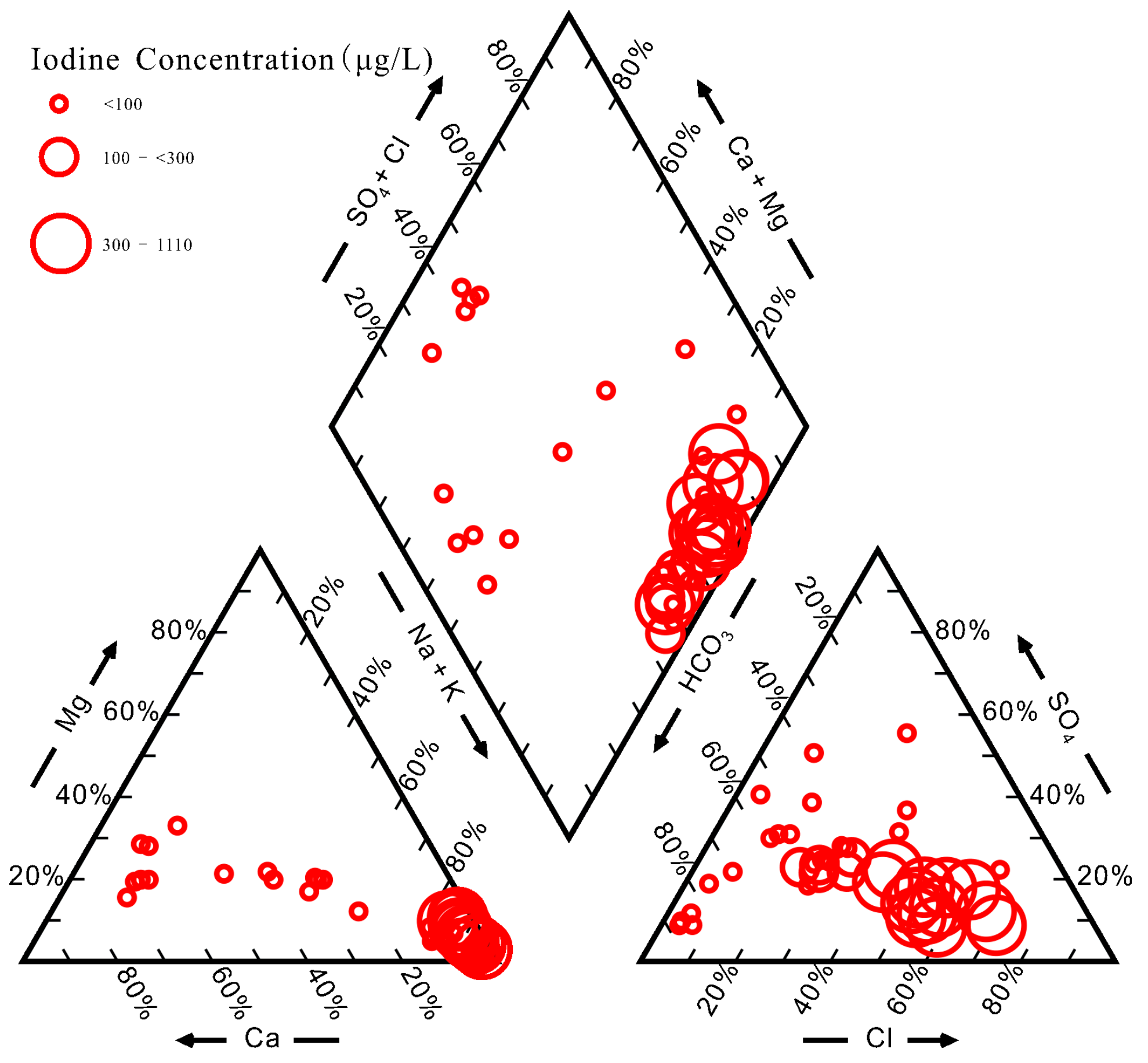

Figure 3

Piper 


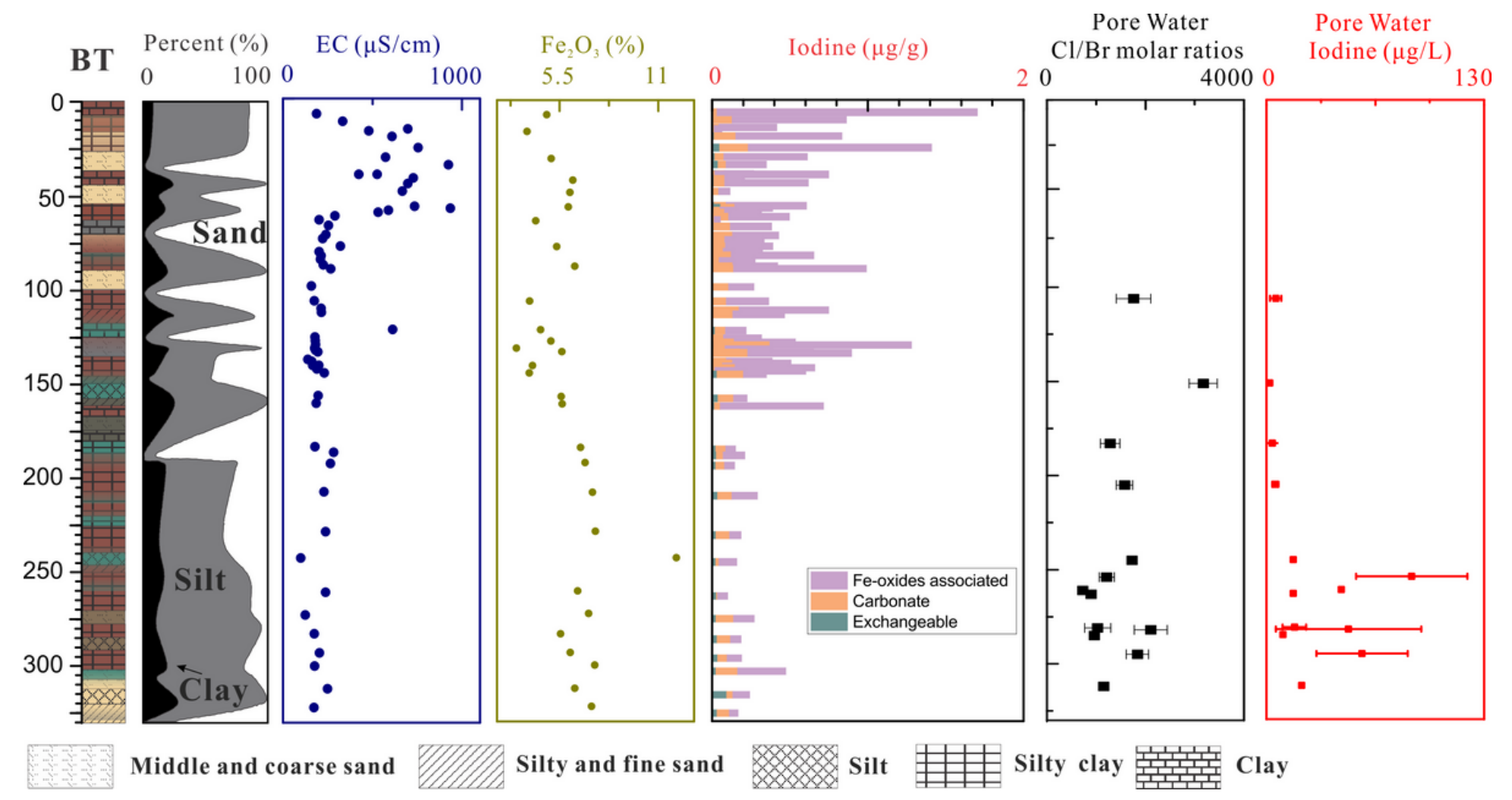

Figure 4

Bore hole data and pore water BT

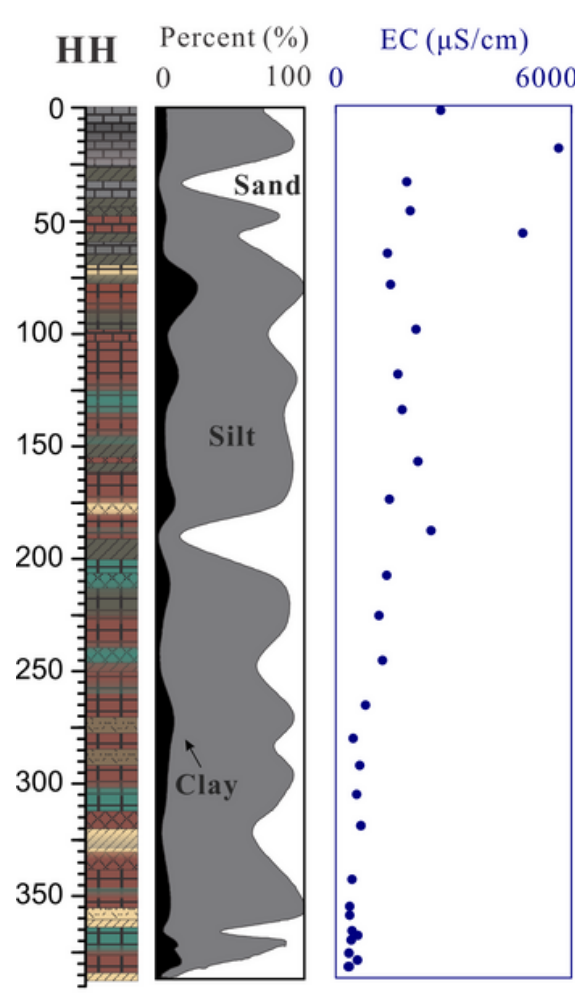

Middle and coarse sand
Iodine $(\mu \mathrm{g} / \mathrm{g})$

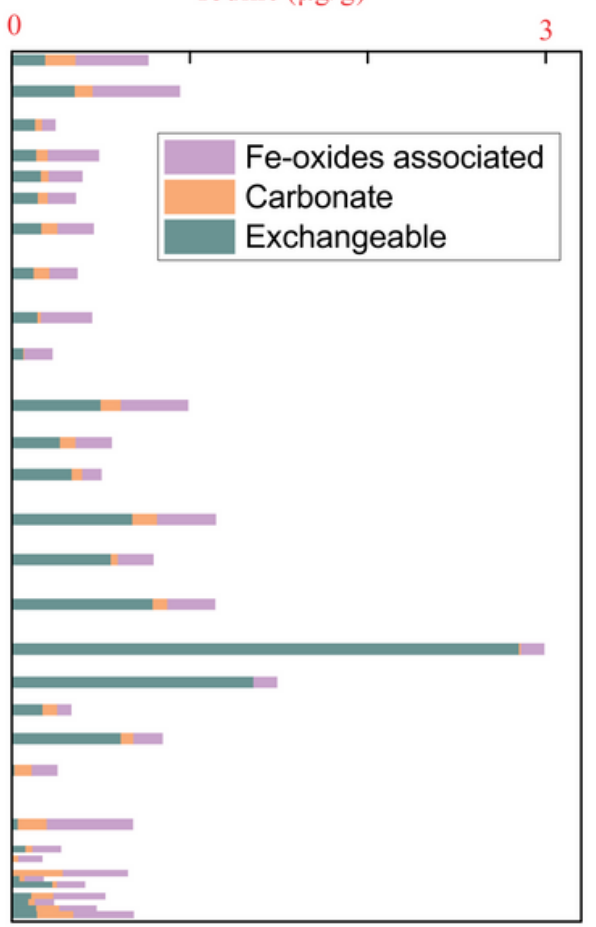

Pore Water $\mathrm{Cl} / \mathrm{Br}$ molar ratios 02000

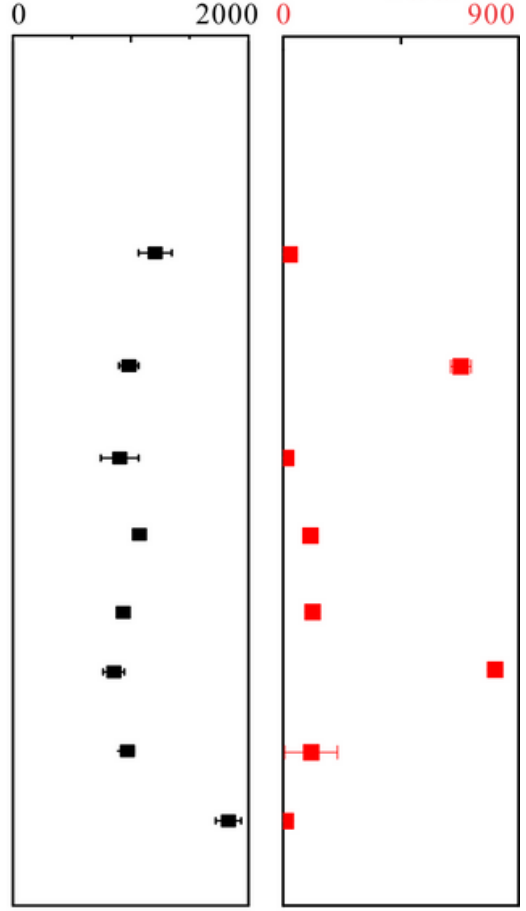

Figure 5 
Bore hole data and pore water $\mathrm{HH}$
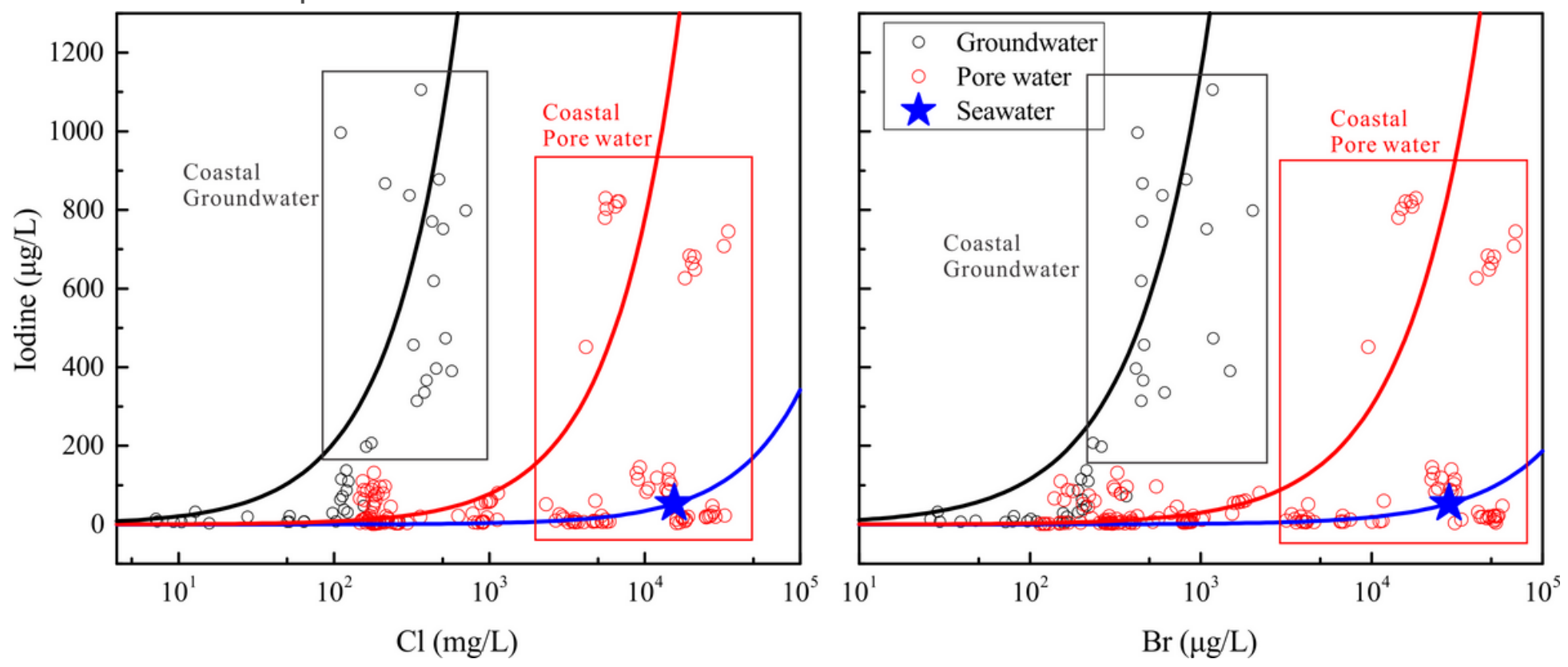

Figure 6

ICI
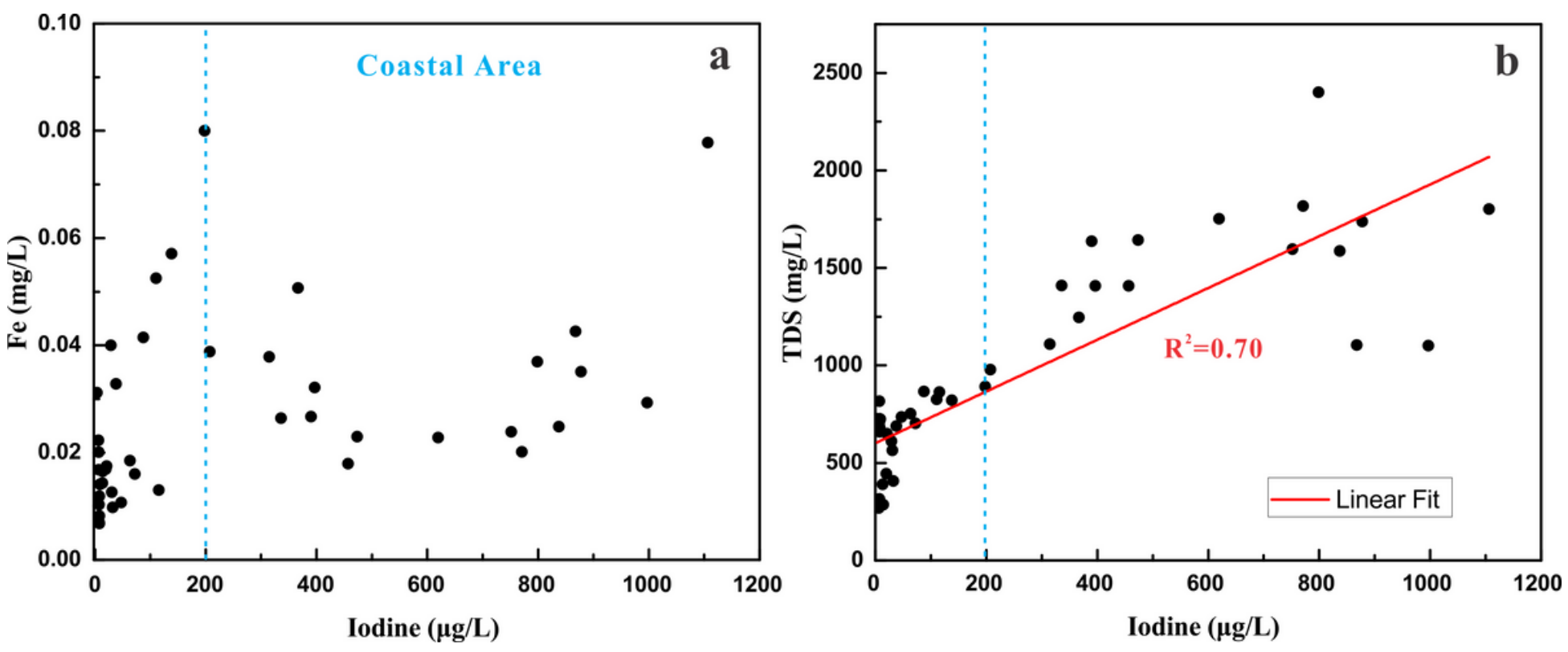

Figure 7

lodine TDS Fe 
A

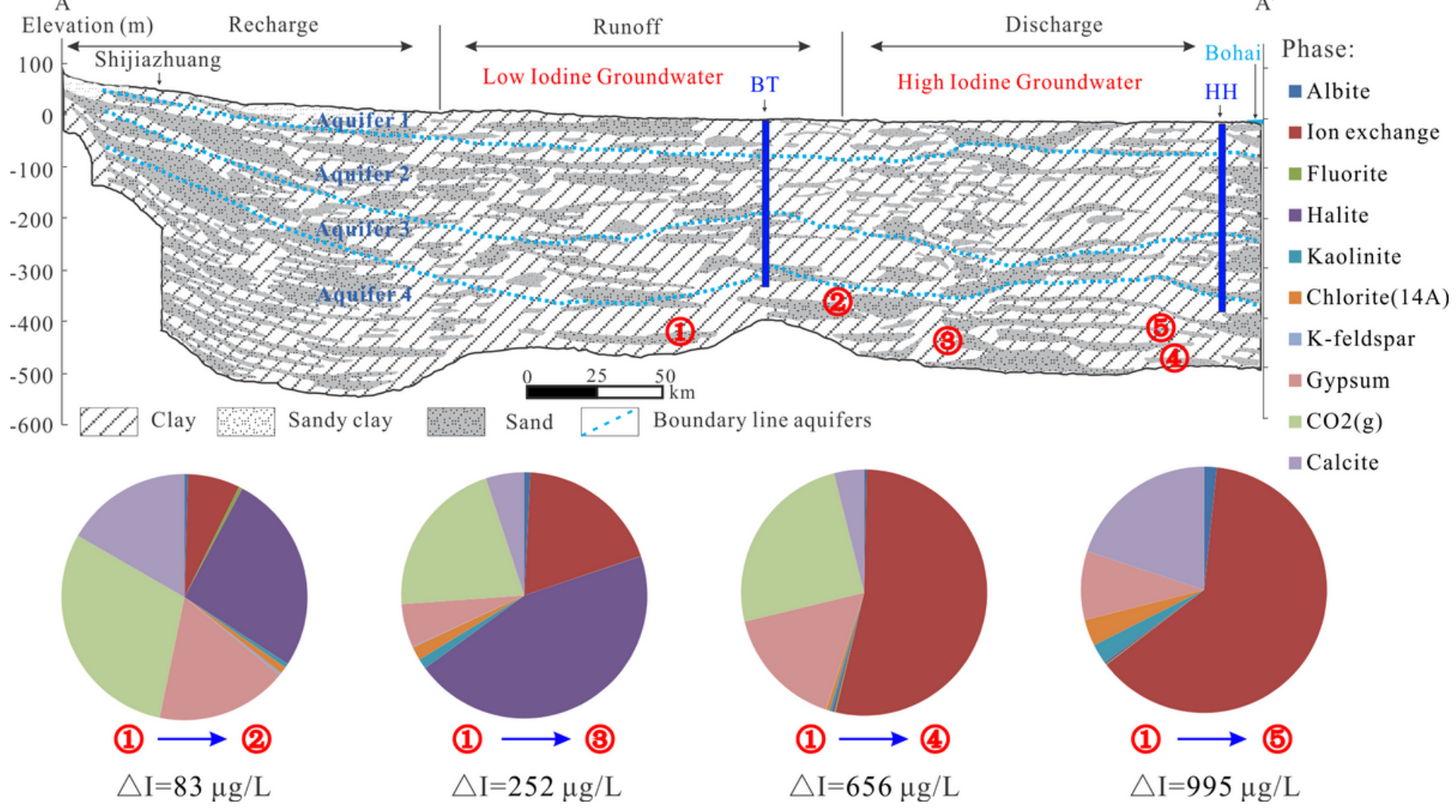

Figure 8

Section Final

\section{Supplementary Files}

This is a list of supplementary files associated with this preprint. Click to download.

- AppendixA.docx 